\title{
Oestrous cycle length and plasma progesterone concentrations following administration of prostaglandin F- $2 \alpha$ early in the bovine oestrous cycle
}

\author{
W. E. Beal*, R. A. Milvae and W. Hansel \\ Department of Physical Biology, Section of Physiology, Cornell University, Ithaca, New York \\ 14853, U.S.A.
}

\begin{abstract}
Summary. Twice daily i.m. injections of PGF-2 $\alpha$ on Days 3 and 4 of the bovine oestrous cycle inhibited progesterone secretion by the corpus luteum and induced precocious oestrus. Injections given less frequently or earlier in the cycle did not induce precocious oestrus but twice daily injection on Days 2 and 3 or Day 4 appeared to inhibit progesterone secretion without affecting oestrous cycle length.
\end{abstract}

\section{Introduction}

Prostaglandin (PG) F-2 $\alpha$ is luteolytic when injected intramuscularly ( $\geq 15 \mathrm{mg}$ ) or infused into the uterine horn $(>2 \mathrm{mg}$ ) ipsilateral to the corpus luteum more than 4 days after oestrus in the cow (Inskeep, 1973). Regardless of the route of administration, a single treatment with PGF-2 $\alpha$ is unable to initiate regression of the bovine corpus luteum during the first 4 days of the oestrous cycle (Lauderdale, 1972; Rowson, Tervit \& Brand, 1972; Inskeep, 1973). This ineffective period has limited the potential use of PGF- $2 \alpha$ for the synchronization of oestrus.

The present experiment was undertaken to determine whether repeated intramuscular injections of PGF-2 $\alpha$ early in the oestrous cycle could induce luteolysis more effectively than a single injection.

\section{Materials and Methods}

Twenty-two (22) Holstein heifers with 19- to 24-day oestrous cycles were randomly assigned to 8 treatment groups. In Groups 1,2 and 3 ( 2 heifers in each) a single intramuscular (i.m.) injection containing $25 \mathrm{mg}$ PGF-2 $\alpha$ (33.5 mg PGF-2 $\alpha$-Tham salt) was administered on Day 2 , Day 3 or Day 4 of the oestrous cycle, respectively (oestrus = Day 0 ). The 3 heifers in each of Groups 4 and 5 received $25 \mathrm{mg}$ PGF- $2 \alpha$ i.m. once daily on Days 2 and 3 or Days 3 and 4, respectively. The remaining heifers received $25 \mathrm{mg}$ PGF- $2 \alpha \mathrm{i} . \mathrm{m}$. twice daily (12-h interval) on Day 4 (Group 6, $N=3$ ), Days 2 and 3 (Group 7, $N=3$ ) or Days 3 and 4 (Group 8, $N=4$ ).

Blood samples were collected twice daily $(08: 00$ and $16: 00 \mathrm{~h})$ via jugular venepuncture on Days 4 through 8 of the oestrous cycle. After Day 8, samples were collected daily $(08: 00 \mathrm{~h})$ until each animal had exhibited oestrus or until the second post-treatment oestrus in animals exhibiting oestrus within $96 \mathrm{~h}$ after PGF-2 $\alpha$ treatment. Sodium citrate was added to each sample to inhibit clotting. Blood samples were centrifuged at $825 \mathrm{~g}\left(4^{\circ} \mathrm{C}\right)$ and aliquots of plasma were removed and stored at $-20^{\circ} \mathrm{C}$ until they could be radioimmunoassayed for progesterone.

* Present address: Department of Animal Science, Virginia Polytechnic Institute and State University, Blacksburg, Virginia 24061, U.S.A. 
Duplicate $0.1 \mathrm{ml}$ aliquots of plasma were extracted with $3 \mathrm{ml}$ petroleum ether. The antiserum to BSA-conjugated progesterone was specific, the major cross-reacting steroids at $50 \%$ inhibition of binding (progesterone $100 \%$ ) being corticosterone (17.03\%), 5 $\beta$-dihydro-

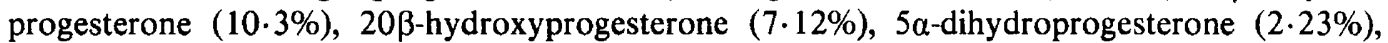
testosterone $(1.94 \%), 20 \alpha$-hydroxyprogesterone $(1.56 \%), 17 \alpha$-hydroxyprogesterone $(1.37 \%)$ and pregnenolone, cortisol, oestrone, oestradiol 17- $\beta$, oestriol, oestradiol-17 $\alpha$, androstenedione, $5 \alpha$-dihydrotestosterone, dehydroepiandrostendione and cholesterol $(<0.6 \%)$. Free and bound progesterone were separated with dextran-coated charcoal. The mean extraction efficiency determined by recovery of labelled progesterone was $88.2 \%$. The percentage recovery of $1,2,4$ and $8 \mathrm{ng}$ authentic progesterone added to plasma from ovariectomized heifers was $112 \cdot 0,98 \cdot 5$, 106.5 and 98.6 , respectively. The minimum sensitivity of the assay was $12.5 \mathrm{pg} / \mathrm{ml}$ and the inter-assay coefficient of variation was $9 \cdot 3 \%$.

During the 30 days before treatment and for 45 days after treatment the cattle were observed at least twice daily for signs of oestrus.

The length of the oestrous cycles during which PGF-2 $\alpha$ was administered (cycle of treatment) and the first cycle after treatment (post-treatment cycle) were compared by one-way analysis of variance with the 8 treatments as fixed effects. Specific comparisons between groups were made by single degree of freedom orthogonal comparisons (Steel \& Torrie, 1960). The concentrations of plasma progesterone during the first 8 days of the oestrous cycle of treatment were compared by split-plot analysis of variance for repeated measurements (Gill \& Hafs, 1971) with treatments and sampling times as fixed effects.

\section{Results and Discussion}

The mean oestrous cycle length in Group 8 was significantly shortened (Table 1). The lengths of the other oestrous cycles of treatment and the post-treatment oestrous cycles were not different $(P>0.05)$.

Table 1. Oestrous cycle lengths (mean \pm s.e.m.) of heifers after treatment with PGF- $2 \alpha^{*}$

\begin{tabular}{cccc}
\hline & \multirow{2}{*}{$\begin{array}{c}\text { No. of } \\
\text { Group }\end{array}$} & \multicolumn{2}{c}{ Oestrous cycle length (days) } \\
\cline { 2 - 4 } & heifers & Cycle of treatment & Post-treatment cycle \\
\hline 1 & 2 & $22.0 \pm 0.0$ & $20.0 \pm 1.0$ \\
2 & 2 & $19.5 \pm 0.5$ & $19.5 \pm 0.5$ \\
3 & 2 & $20.0 \pm 1.0$ & $18.5 \pm 0.5$ \\
4 & 3 & $20.0 \pm 0.0$ & $19.0 \pm 1.0$ \\
5 & 3 & $20.3 \pm 0.9$ & $22.3 \pm 0.9$ \\
6 & 3 & $22.3 \pm 2.3$ & $20.0 \pm 1.0$ \\
7 & 3 & $21.0 \pm 0.0$ & $19.5 \pm 0.3$ \\
8 & 4 & $6.2 \pm 0.1 \dagger$ & $18.3 \pm 0.8$ \\
\hline
\end{tabular}

* See 'Materials and Methods' for explanation of treatment groups, cycle of treatment and post-treatment cycle.

$\dagger$ Significantly different from other treatment and posttreatment cycles $(P<0.005)$.

Analysis of variance of the concentrations of jugular plasma progesterone on Days 4 through 8 revealed a significant interaction $(P<0.005)$ between the effects of the treatments and the day of the oestrous cycle. This interaction is indicative of differences among treatment groups in the rate of increase in the concentrations of plasma progesterone during the days following administration of PGF- $2 \alpha$ (Text-fig. 1). Concentrations of plasma progesterone in the 


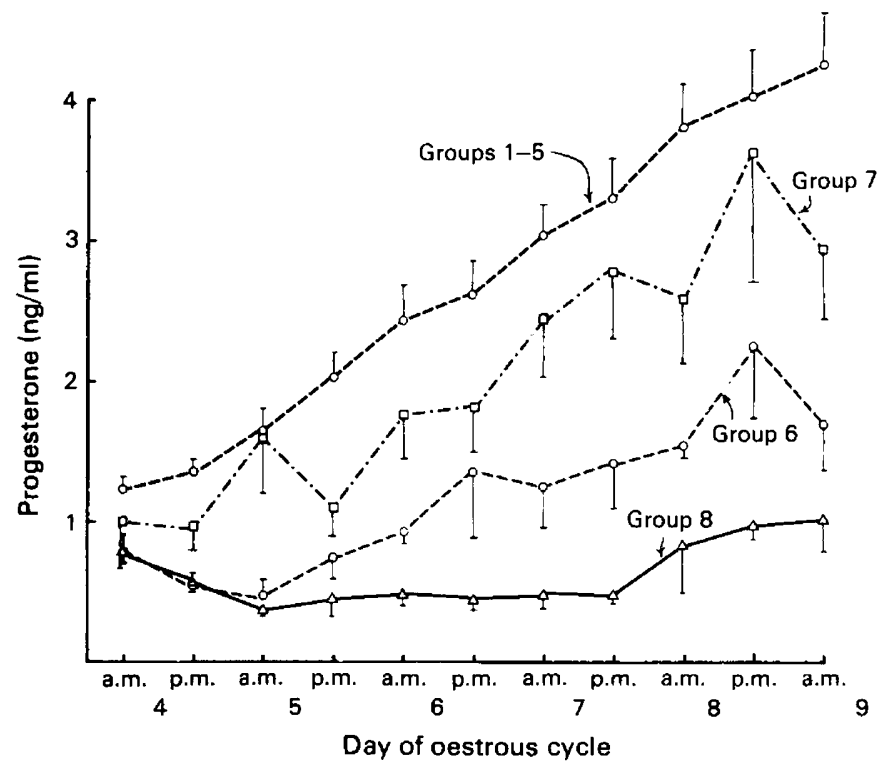

Text-fig. 1. Mean ( \pm s.e.m.) concentrations of plasma progesterone in heifers after PGF- $2 \alpha$ administration. See 'Materials and Methods' for explanation of treatment groups.

animals with shortened oestrous cycles (Group 8) were consistently lower than those of any other group. Concentrations remained $<0.5 \mathrm{ng} / \mathrm{ml}$ while the animals were in oestrus and by Day 9 increased to only $1 \mathrm{ng} / \mathrm{ml}$. The increase in progesterone concentrations after the detection of oestrus in this group is believed to reflect the development of 'new' corpora lutea, but this is an assumption since the ovaries were not palpated.

The lengths of the oestrous cycles in Groups 6 and 7 were not affected but concentrations of plasma progesterone in these animals were consistently lower than those in animals injected only once daily (Text-fig. 1). On Day 15 (cycle of treatment), mean plasma progesterone concentrations in Groups $6(3.1 \mathrm{ng} / \mathrm{ml})$ and $7(3.2 \mathrm{ng} / \mathrm{ml})$ were still lower $(P<0.05)$ than those in animals injected only once daily $(4.7 \mathrm{ng} / \mathrm{ml})$. These results suggest that although these treatments did not shorten the oestrous cycle, they depressed concentrations of peripheral plasma progesterone throughout the cycle.

The effects of repetitive PGF- $2 \alpha$ treatments in this experiment were similar to those of daily injections of oxytocin on Days 1-7 which shortened the oestrous cycle and induced precocious oestrus (Armstrong \& Hansel, 1959). The reduction of cycle lengths, corpora lutea weights and luteal progesterone concentrations after oxytocin treatment were related to the dose, duration and frequency of injections (Donaldson \& Takken, 1968; Donaldson, 1969). Twice daily administration of oxytocin on Days 4, 5 and 6 of the oestrous cycle caused a significant increase $(P<0.005)$ in uterine venous plasma concentrations of PGF (Milvae \& Hansel, 1980) but this increase in uterine vein PGF was not reflected in concurrently collected samples of ovarian arterial plasma. This suggests that some factor other than PGF or a mechanism other than local venoarterial transfer may be involved in mediating the inhibitory effects of oxytocin.

Repeated injections of PGF-2 $\alpha$ were more effective in inhibiting luteal function than a single injection. Elving, Brand \& de Bois (1975), using 2 injections of PGF-2 $\alpha$ at a 24-h interval, could initiate regression of corpora lutea and induce oestrus in cows when the injections were administered before Day 5 of the oestrous cycle.

In our experiment, twice daily injections of PGF- $2 \alpha$ on Days 2 and 3 of the cycle seemed less effective in inhibiting the secretion of progesterone by corpora lutea than two injections on Day 4. It therefore appears that maturation of the corpus luteum is associated with increased 
sensitivity to PGF- $2 \alpha$ treatment. This may be related to the rapid increase in the concentration and total content of specific PGF-2 $\alpha$ receptors in the bovine corpus luteum early in the oestrous cycle (Bartol et al., 1977). Neither the Group 6 nor 7 treatment was capable of inducing precocious oestrus. The 2 injections of PGF- $2 \alpha$ on Day 4 had to be preceded by 2 injections on Day 3 in order to initiate complete regression of the corpora lutea and induce precocious oestrus. Therefore, the frequent injections of PGF- $2 \alpha$ had a cumulative effect. In general, it seems that the ability of a given treatment to inhibit luteal function in cattle depended on the interaction of two factors; age of the corpus luteum and the frequency of PGF-2 $\alpha$ administration.

\section{References}

Armstrong, D.T. \& Hansel, W. (1959) Alteration of the bovine estrous cycle with oxytocin. J. Dairy Sci. 42, 533-542.

Bartol, F.F., Kimball, F.A., Thatcher, W.W., Bazer, W., Chenault, J.R., Wilcox, C.J. \& Kittock, R.J. (1977) Follicle, luteal and uterine parameters during the bovine estrous cycle. J. Anim. Sci. 45, Suppl. 1, 34, Abstr.

Donaldson, L.E. (1969) Effect of continued daily injections of oxytocin on oestrous cycle length and reproductive tract morphology in the cow. J. Reprod. Fert. 18, 259-263.

Donaldson, L.E. \& Takken, A. (1968) The effect of exogenous oxytocin on corpus luteum function in the cow. J. Reprod. Fert. 17, 373-383.

Elving, L., Brand, A. \& de Bois, C.H.W. (1975) Oestrus synchronization and fertility in heifers treated with prostaglandin $\mathrm{F}_{2} \alpha$. Tijdschr. Diergeneesk. 100, 758762.
Gill, J.L. \& Hafs, H.D. (1971) Analysis of repeated measurements of animals. J. Anim. Sci. 33, 331-336.

Inskeep, E.K. (1973) Potential uses of prostaglandins in control of reproductive cycles of domestic animals. $J$. Anim. Sci. 36, 1149-1157.

Lauderdale, J.W. (1972) Effects of PGF2 $\alpha$ on pregnancy and estrous cycle of cattle. J. Anim. Sci. 35, 246, Abstr.

Milvae, R.A. \& Hansel, W. (1980) Concurrent uterine venous and ovarian arterial prostaglandin F concentrations after oxytocin administration. J. Reprod. Fert. 60 (in press).

Rowson, L.E.A., Tervit, R. \& Brand, A. (1972) The use of prostaglandin for synchronization of oestrus in cattle. J. Reprod. Fert. 29, 145, Abstr.

Steel, R.G.D. \& Torrie, J.H. (1960) Principles and Procedures of Statistics. McGraw-Hill, New York.

Received 9 October 1979 